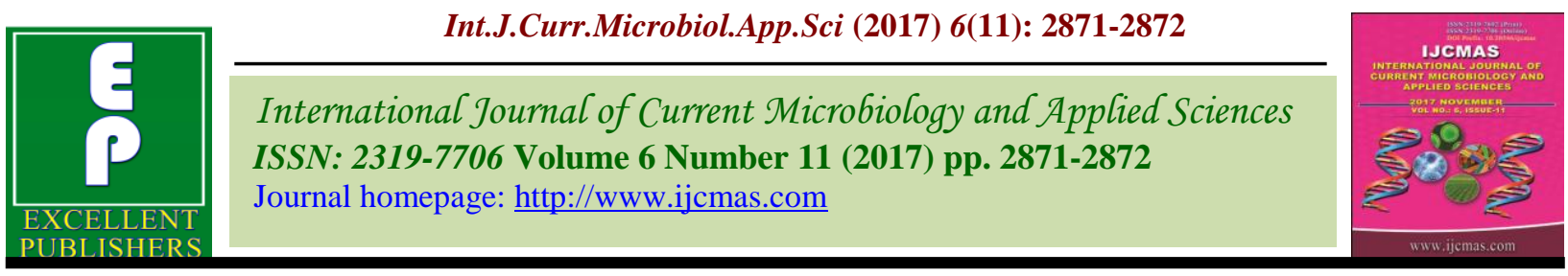

Case Study

https://doi.org/10.20546/ijcmas.2017.611.338

\title{
Alternate Feed Stock for Urban House Hold Biogas Plant
}

\author{
M. Suguna Devakumari* \\ School of Agriculture and Biosciences, Karunya University, Coimbatore, Tamil Nadu, India \\ *Corresponding author
}

\section{A B S T R A C T}

Keywords

Bio gas, Alternate feed stock, Kitchen waste, Digester.

\section{Article Info}

Accepted:

20 September 2017

Available Online:

10 November 2017
The bio-gas produced from food waste, decomposable organic material and kitchen waste, consisting of methane and a little amount of carbon di oxide is an alternative fuel for cooking gas (LPG). Also, the waste materials can be disposed off efficiently without any odor or flies and the digested slurry from the bio-gas unit can be used as organic manure in the garden. The major components of the bio-gas plant are a digester tank, an inlet for feeding the kitchen waste, gas holder tank, an outlet for the digested slurry and the gas delivery system for taking out and utilizing the produced gas. In this study, together with food waste alternate feed stocks were tried and the production of biogas was sufficient for the entire cooking need of the household and also supports the biogas based water heater in the house.

\section{Introduction}

The pressure of dwindling conventional feedstock for the biogas plants, R\&D efforts have been initiated for alternate feedstocks viz., kitchen waste, expired packed food materials especially in the urban households where availability of cowdung is a limited resource. Co-digestion of food waste with cow dung or other feed stocks with low carbon content can improve process stability and methane production (Gashaw and Teshita, 2014). In this study the performance of alternate feed stocks were evaluated for the production of biogas in portable type biogas plants in urban areas.

\section{Materials and Methods}

In Saibaba Colony, Coimbatore, three numbers of biogas plants, Sakthi Surabhi model, Biotech model and Modified KVIC model (Stainless Steel) with capacities of $1 \mathrm{~m}^{3}, 1 \mathrm{~m}^{3}$ and $2 \mathrm{~m}^{3}$ respectively. In the house of Mr. Sridhar is functioning completely using alternate feedstock such as kitchen solid wastes and waste water from kitchen, expired packaged foods like noodles, fruit essence, chocolates and polo candy.

Gas flow meter was attached to the biogas plants and readings were taken on daily basis for gas production.

The BOD, organic carbon content and $\mathrm{pH}$ of the feed stock and the slurry was analyzed in the laboratory at Department of Bioenergy, Tamil Nadu Agricultural University, Coimbatore.

\section{Results and Discussion}

There was a considerable reduction in BOD from $640 \mathrm{mg} \mathrm{L}^{-1}$ (inlet) to $303.2 \mathrm{mg} \mathrm{L}^{-1}$ (Outlet) which is about $52.6 \%$ reduction. The Organic Carbon 
content reduced from $34.5 \%$ (inlet) to $22.8 \%$ (outlet) which is about $33.9 \%$ reduction. The $\mathrm{pH}$ of the inlet was 7.12 and the outlet was 6.85 . The average methane content is 64\% (Fig. 1; Table 1).

Fig.1 Gas production on daily basis according to flow meter readings

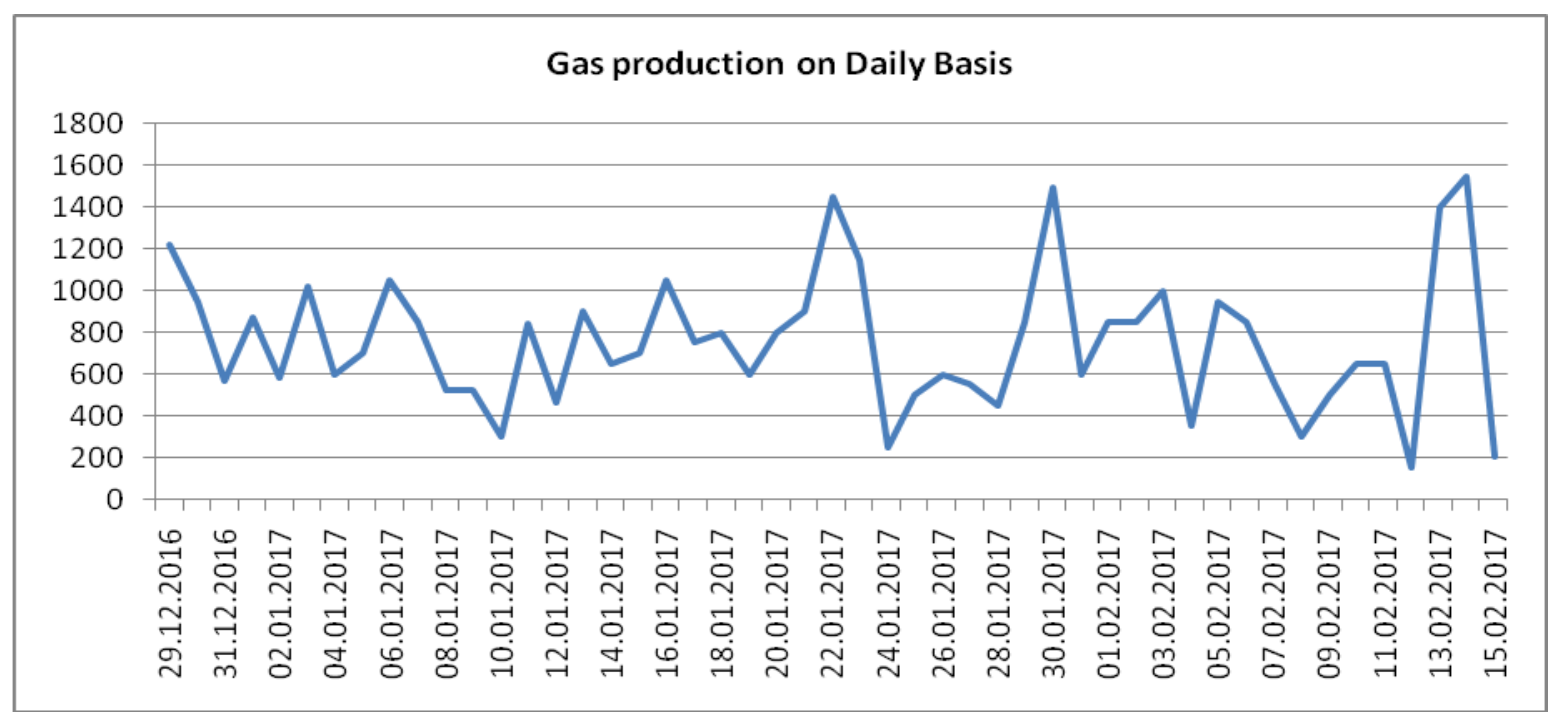

Table.1 Quality parameters of the inlet (feed stock) and outlet (slurry)

\begin{tabular}{|l|l|c|c|}
\hline S.No & \multicolumn{1}{|c|}{ Parameters } & Inlet & Outlet \\
\hline 1. & BOD mg L $^{-1}$ & 640 & 303.2 \\
\hline 2. & OC \% & 34.5 & 22.8 \\
\hline 3. & $\mathrm{pH}$ & 7.12 & 6.85 \\
\hline
\end{tabular}

The production of biogas was sufficient for the entire cooking need of the household and also supports the biogas based water heater in the house. This proves that utilization of alternate feed stock, easily available at low cost or free of cost, substitutes the requirement of cow dung and agricultural wastes which are meagerly available in urban areas. Moreover the digested slurry with optimum $\mathrm{pH}$ and organic carbon content could be utilized as organic manure for the kitchen garden. According to Sharada et al., (2016), food waste getting converted into biogas not only becomes an alternative source of energy but also burning the biogas helps in reducing the methane production from organic waste which is one of the greenhouse gases and contributing to environmental clean-up.

\section{References}

Gashaw, A and Teshita, A. 2014. Co-Digestion of Ethiopian Food Waste with Cow Dung for Biogas Production. International Journal of Research.1:476-500.

Sharada, S., Surendra Babu, G., and Hema Latha, K. 2016. Production of biogas from kitchen waste. International Journal of Scientific Development and Research.1: 218-221.

\section{How to cite this article:}

Suguna Devakumari, M. 2017. Alternate Feed Stock for Urban House Hold Biogas Plant. Int.J.Curr.Microbiol.App.Sci. 6(11): 2871-2872. doi: https://doi.org/10.20546/ijcmas.2017.611.338 